\title{
GIARDIA INTESTINALIS ASSEMBLAGES AMONG EGYPTIAN SYMPTOMATIC/ASYMPTOMATIC CASES IN CAIRO

\author{
By
}

DINA S. NASR ${ }^{1}$, HEBAT-ALLAH S. A. YOUSOF ${ }^{1}{ }^{\star}$, KEVIN TYLER $^{2}$, AYMAN EL-BADRY ${ }^{3}$, JOSE M. RUBIO ${ }^{4}$ and NADIA A. E. EL-DIB ${ }^{1}$

Department of Medical Parasitology ${ }^{1}$, Faculty of Medicine, P.O. Box 11562, Cairo University, Egypt, Bio-Medical Research Centre ${ }^{2}$, Norwich Medical School, University of East Anglia, Norwich, Norfolk, United Kingdom, Department of Microbiology-

Medical Parasitology Section ${ }^{3}$, College of Medicine, University of Dammam,

Dammam, Saudi Arabia and Institute de Microbiologia ${ }^{4}$,

Instituto de Salud Carlos III, Madrid, Spain

(*Correspondence: drhebasalah@kasralainy.edu.eg, drhebasalah@hotmail.com)

\begin{abstract}
Giardia intestinalis is frequent enteric protozoa, affecting humans worldwide. Human infections are mainly caused by two genetically different assemblages call A \& B. This cross-sectional study characterized the Giardia genotypes isolated from the stool of symptomatic and asymptomatic Egyptians in Cairo and correlated these genotypes with the demographic and clinical data of the cases. Stool samples were collected from 389 individuals (245 complaining of gastrointestinal (GIT) symptoms and 144 apparently healthy asymptomatic individuals), and microscopically examined. Positive Samples for $G$. intestinalis were molecularly characterized by Copro-nPCR targeting beta-giardin gene, and then analyzed by RFLP for assemblage identification. Giardia was detected in 62 samples (15.9\%); 53 samples in symptomatic cases (21.6\%) and 9 samples in asymptomatic individuals (6.25\%). DNA of positive samples was amplified by nPCR-RFLP assays. There was a significant predominance of assemblage B among symptomatic (82.7\%) and asymptomatic (77.8\%) groups, while the rest of samples had assemblage A. Among the clinical data, only flatulence was significantly associated with Giardia infection with assemblage B. Assemblage B is the predominant genotype found in Egypt in symptomatic and asymptomatic patients suggesting an anthropologic transmission cycle.
\end{abstract}

Key Words: Giardia; genotyping; Assemblage; nPCR-RFLP; beta-giardin.

\section{Introduction}

Giardia intestinalis ( $G$. intestinalis) is a flagellated micro-organism that represents an essential global cause of diarrhea in humans (Feng and Xiao, 2011). WHO had included Giardiasis in the Neglected Diseases Initiative since 2004 due its influence on health (Savioli et al, 2006). The parasite can cause gastrointestinal infections extending from mild to severe or protracted disease. The clinical severity of Giardiasis depends on host factors (e.g. nutritional status, microbiome and immunity) as well as parasitic factors (e.g. infecting strain and infectious dose) (Tsourdi et al, 2014). The prevalence of giardiasis in African children can exceed 30\% (Thompson and Smith, 2011).

Despite the widespread use of microscopy in epidemiological analyses, the real prevalence of giardiasis is underestimated (Ver- weij et al, 2004). PCR-based assays have higher sensitivity than microscopy detecting the parasite in stool samples (Ghosh et al, 2000). Molecular tools were used to offer better understandings of the taxonomy, host variety and transmission pathways of Giardia (Fayer et al, 2000).

G. intestinalis complex isolates are categorized into eight different genetic assemblages from $\mathrm{A}$ to $\mathrm{H}$ based on the characterization of their small subunit ribosomal RNA (ssurRNA), the glutamate dehydrogenase (gdh), the $\beta$-giardin (bg), the triose phosphate isomerise (tpi), the elongation factor 1-alpha $(\mathrm{ef}-1 \alpha)$, and the GLORF-C4 genes (Cacciò and Rayan, 2008; Monis et al, 2009). Assemblages A \& B caused human infection worldwide, but the relative prevalence of assemblages varies geographically (Thompson and Monis, 2004). Although many in- 
vestigations have been undertaken to relate the severity of the infection with a particular assembly (Sahagun et al, 2008), there remains no clearly demonstrated predictable relationship between the parasite assemblages and the severity of infection (Cacciò and Rayan, 2008). Very little information is known about the assemblages' diversity and multi-locus genotype in North Africa cases. In the existing study, the genotypes of $G$. intestinalis isolated from symptomatic and apparently healthy asymptomatic cases attending outpatient clinics in Kasr Al-Ainy University Hospitals were identified from the collected stool samples which were positive for Giardia by microscopy and then typed using PCR techniques (Nested PCR using beta-giardin gene \& PCR-RFLP). The detected assemblages were correlated with the symptoms and demographic data of the cases.

\section{Methodology}

Study cases: This cross-sectional study was done on 389 Egyptian cases attending outpatient clinics in Kasr Al-Ainy University Hospitals to characterize the genotypes of Giardia intestinalis in the symptomatic/asymptomatic cases. The studied population was divided into 2 groups; GI: which included 245 patients suffering from GIT symptoms and GII with 144 persons not suffering from any GIT symptoms.

The study was permitted by the Ethical Board of the Medical Parasitology Department and the Ethical Board of Faculty of Medicine, Cairo University. Consents were taken from adult cases and custodians of the children included in the study before sample collection, and participation was optional. Complete medical history was obtained from each participant before doing any investigations.

Collection and processing of samples: One fecal sample from each participant was obtained in a dry, clean, leak-proof plastic container. A questionnaire containing demographic, clinical and environmental data was obtained with each sample.
Each sample was divided into three portions; a small portion for direct smear examination, another portion was preserved in tight containers using formalin-saline fixative for microscopic analysis, and the third portion of the sample was stored without any preservatives at $-20^{\circ} \mathrm{c}$ in Eppendorf tubes for molecular studies.

Coproscopic examination of samples: Wet smears stained with Lugol's iodine from all stool samples were immediately examined microscopically and Negative samples were subjected to concentration using the modified Ritchie's biphasic method (Garcia, 2007) before reexamined microscopically.

Copro-nPCR assays: 1- Genomic DNA extraction from stool samples: Following a light microscopy analysis, positive Giardia samples were submitted to DNA extraction, in the Laboratory of Molecular Medical Parasitology, Parasitology Department, Kasr Al-Ainy using a Favor Prep stool DNA isolation Mini Kit (Favorgen Biotech corporation Ping-Tung 908, Taiwan, Cat. No. FASTI001). Extraction of genomic DNA was performed according to the manufacturer's guide and modified according to Fontaine and Guillot (2006). The purified DNA was measured for the concentration and purity (Qubit ${ }^{\circledR}$ 2.0 Fluorometer) then used immediately or stored at $-20^{\circ} \mathrm{C}$ till used.

2- DNA amplification using Nested-PCR: Extracted genomic DNA was analyzed by nested-PCR using $\beta$-giardin (bg) gene. The first amplification reaction generated a $753 \mathrm{bp}$ fragment using the primer pair set G7; 5'-AAG CCC GAC GAC CTC ACC CGC AGT GC -3' and G759; 5'-CAT AAC GAC GCC ATC GCG GCT CTC AGG AA3' (Caccio`et al, 2002). The second amplification produced a $511 \mathrm{bp}$ fragment using the primer pair set 2005F; 5'- GAA C GA ACG AGA TCG AGG TCC G -3' and 2005R; 5'CTC GAC GAG CTT CGT GTT-3' (Lallea et al, 2005).

The primary amplification was carried out with 10 minutes of initial denaturation at $95^{\circ} \mathrm{C}$ followed by 35 cycles of $95^{\circ} \mathrm{C}$ for 30 
seconds, $65^{\circ} \mathrm{C}$ for 30 seconds and $72^{\circ} \mathrm{C}$ for 1 minute and a final extension of 10 minutes at $72^{\circ} \mathrm{C}$. Samples were keeping at $4^{\circ} \mathrm{C}$ until its analysis. The nested-PCR conditions were the same except that annealing temperature was performed at $53^{\circ} \mathrm{C}$.

All primary reactions contained $12.5 \mu \mathrm{L} 2 \mathrm{x}$ Master Mix (Thermo scientific, UK, Lot no.\#K1081), $1 \mu 1(0.2 \mu \mathrm{M})$ of each primer, $0.1 \mu 1 \mathrm{Taq}$ Polymerase (5units/ $\mu \mathrm{l}$ ) for reaction activation, $3 \mu \mathrm{L}$ of template DNA \& 7.4 $\mu \mathrm{l}$ of double distilled water $\left(\mathrm{ddH}_{2} \mathrm{O}\right)$. All nPCR reactions contained $12.5 \mu \mathrm{L} 2 \mathrm{x}$ Master Mix, $1 \mu 1(200 \mathrm{nM})$ of each primer, $0.1 \mu 1 \mathrm{Taq}$ Polymerase (5units/ $\mu \mathrm{l}$ ), $1 \mu \mathrm{L}$ of template DNA and $9.4 \mu \mathrm{l}$ of $\mathrm{ddH}_{2} \mathrm{O}$ to obtain a final volume of $25 \mu \mathrm{L}$.

Two negative control samples were routinely used for every extraction series and in every PCR run, which contained only the reagents and no template. DNA of the positive control sample was also involved in the reactions. For detection of possible inhibitors, PCR-inhibition control sample containing the sample DNA and the DNA of the positive sample was run along each sample.

Visualization of the obtained amplified sequences was done using 1.5\% agarose gel electrophoresis following staining by ethidium bromide (Chevallet et al, 2006).

Genetic characterization of $G$. intestinalis: The positive n-PCR samples were then analyzed by PCR-RFLP, to genetically characterize the $G$. intestinalis assemblages. PCRRFLP was done by digestion of the secondary products of $n-P C R$ with 10 units/ $\mu 1$ of the endonuclease enzyme HaeIII $(511 \mathrm{pb}$ fragment) (New England Biolabs Inc., USA). Digestion of PCR products of positive samples for Giardia after amplification was done in accordance to the manufacturer's guidelines. The following were added: PCR reaction mixture $(10 \mu l)$, Nuclease-free water $(17 \mu \mathrm{l})$, Green buffer $(2 \mu \mathrm{l}$.) \& HaeIII $(1 \mu \mathrm{l})$ were added to reach a total a volume of $30 \mu \mathrm{L}$ for $4 \mathrm{~h}$ at $37^{\circ} \mathrm{C}$.

The restriction fragments were further examined by $3 \%$ Metaphor agarose gel electrophoresis stained by ethidium bromide, the fragments were visualized by Ultra-Violet Trans-illumination to determine $G$. intestinalis assemblages. A squematic representation of the expected bands of Giardia assemblages was given (Fig. 1).

\begin{tabular}{|l|l|l|l|l|l|l|}
\hline \multirow{2}{*}{ bp } & \multicolumn{5}{|c|}{ Giardia Assemblages } \\
\hline & A & B & C & D & E & F \\
\hline 201 & & & & & & \\
\hline 200 & & & & & & \\
\hline 194 & & & & & & \\
\hline 186 & & & & & & \\
\hline 150 & & & & & & \\
\hline 117 & & & & & & \\
\hline 110 & & & & & & \\
\hline 102 & & & & & & \\
\hline 84 & & & & & & \\
\hline 50 & & & & & & \\
\hline 26 & & & & & & \\
\hline 24 & & & & & & \\
\hline 15 & & & & & & F. 1 \\
\hline
\end{tabular}

Fig. 1: Diagram of expected Giardia assemblage profiles after Hae III digestion of nPCR products

Statistical analysis: Data were analyzed using SPSS version 16. Percentages were used to analyze the categorical and quantitative variables. Pearson's chi-squared and 
Fisher's Exact Tests were used for categori- $\quad$ was set as $p<0.05$. cal data. Statistical significance of results

\section{Results}

Clinical and demographic data of the stud- under 18 years old with an equilibrated peried population: Most of the participants are centage between males and females (Tab. 1). Table 1: The demographic and clinical data of the studied population

\begin{tabular}{|c|c|c|c|c|c|}
\hline \multicolumn{2}{|c|}{ Studied population } & & Symptomatic $(\mathrm{n}=245)$ & Asymptomatic ( $\mathrm{n}=144)$ & Total $(\mathrm{n}=389)$ \\
\hline \multirow{5}{*}{$\begin{array}{l}\text { Demographic } \\
\text { data }\end{array}$} & \multirow{3}{*}{ Age } & $<18$ & $225(91.9 \%)$ & $132(91.7 \%)$ & $357(91.8 \%)$ \\
\hline & & $19-49$ & $17(6.9 \%)$ & $9(6.2 \%)$ & $26(6.7 \%)$ \\
\hline & & $>50$ & $3(1.2 \%)$ & $3(2.1 \%)$ & $6(1.5 \%)$ \\
\hline & \multirow{2}{*}{ Gender } & Males & $120(49 \%)$ & $73(50.7 \%)$ & $193(49.6 \%)$ \\
\hline & & Females & $125(51 \%)$ & $71(49.3 \%)$ & $196(50.4 \%)$ \\
\hline \multirow{4}{*}{$\begin{array}{l}\text { Clinical } \\
\text { Data }\end{array}$} & & Diarrhea & $151(61.6 \%)$ & ---- & \\
\hline & & Abdominal pain & $150(61.2 \%)$ & ----- & \\
\hline & & Flatulence & $138(53.9 \%)$ & ----- & \\
\hline & & Fever & $33(13.5 \%)$ & ----- & \\
\hline
\end{tabular}

Parasitological coproscopic analysis: $\mathrm{Mi}-$ croscopic examination was performed for all samples. Giardia was the most commonly detected pathogen in the symptomatic group being isolated in $22.5 \%$ of the diarrheal cases, $13.3 \%$ of cases with abdominal pain, $10.1 \%$ of flatulence cases and $9.1 \%$ of cases with fever. Also, Giardia was also the most prevalent pathogen detected in the asymptomatic cases being present in $13.2 \%$ of cases. The prevalence of Giardia was statistically significant higher in symptomatic than in asymptomatic group $(P<0.001)$ and the main complaint of positive cases were diarrhea and abdominal pain representing $79.1 \%$ and $46.5 \%$, of cases respectively $(P<0.001)$.

Regarding the age distribution among the positive Giardia cases there was significant predominance of Giardia infection among cases below the age of 18 years, the study had shown $95.4 \%$ of Giardia cases below the age 18 years $(P<0.001)$ and only $4.6 \%$ were between $19 \& 49$ years among the symptomatic group. Besides, all asymptomatic Giardia cases were below the age of 18 years $(P<0.001)$ but without significant difference concerning the age distribution between the groups $(P=0.822)$. Similarly, difference in gender between the positive symptomatic and asymptomatic cases there was not significant $(P=0.396)$.

Copro-nPCR-RFLP assays analysis: Out of 389 cases, 62 were positive for Giardia cysts by microscopy and were subjected to nested-PCR. Nested-PCR assay resulted in 52 positive and 10 negative cases. Regarding the distribution of Giardia assemblages among the studied groups, there was a significant predominance of assemblage $\mathrm{B}$ in all groups $(P<0.001$ (Figs. 2, 3).

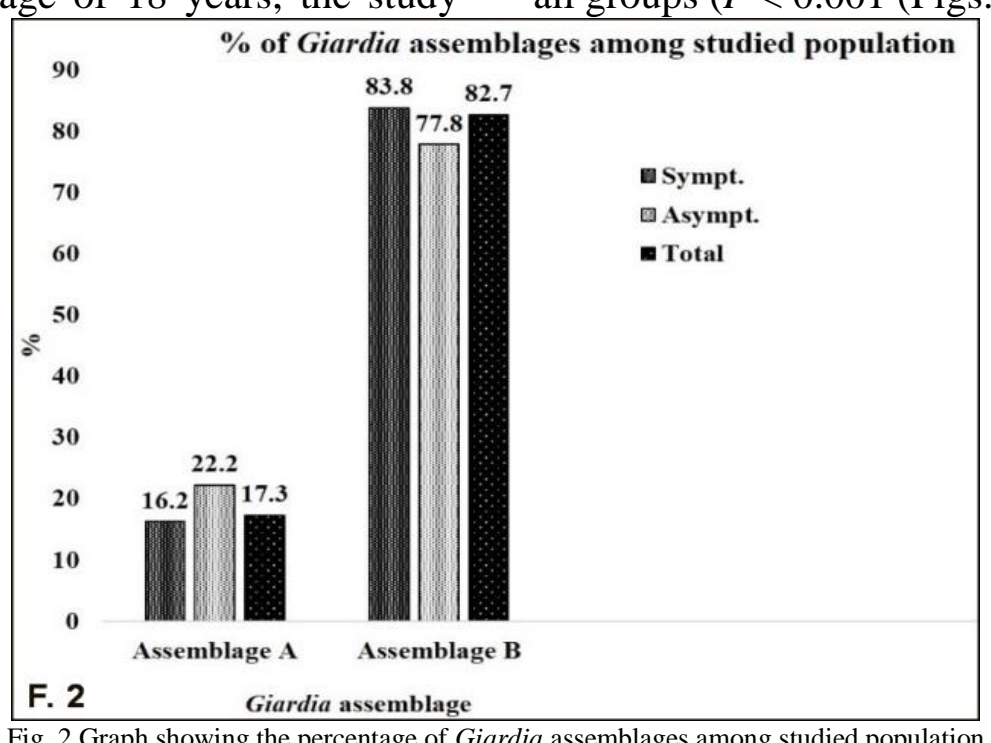




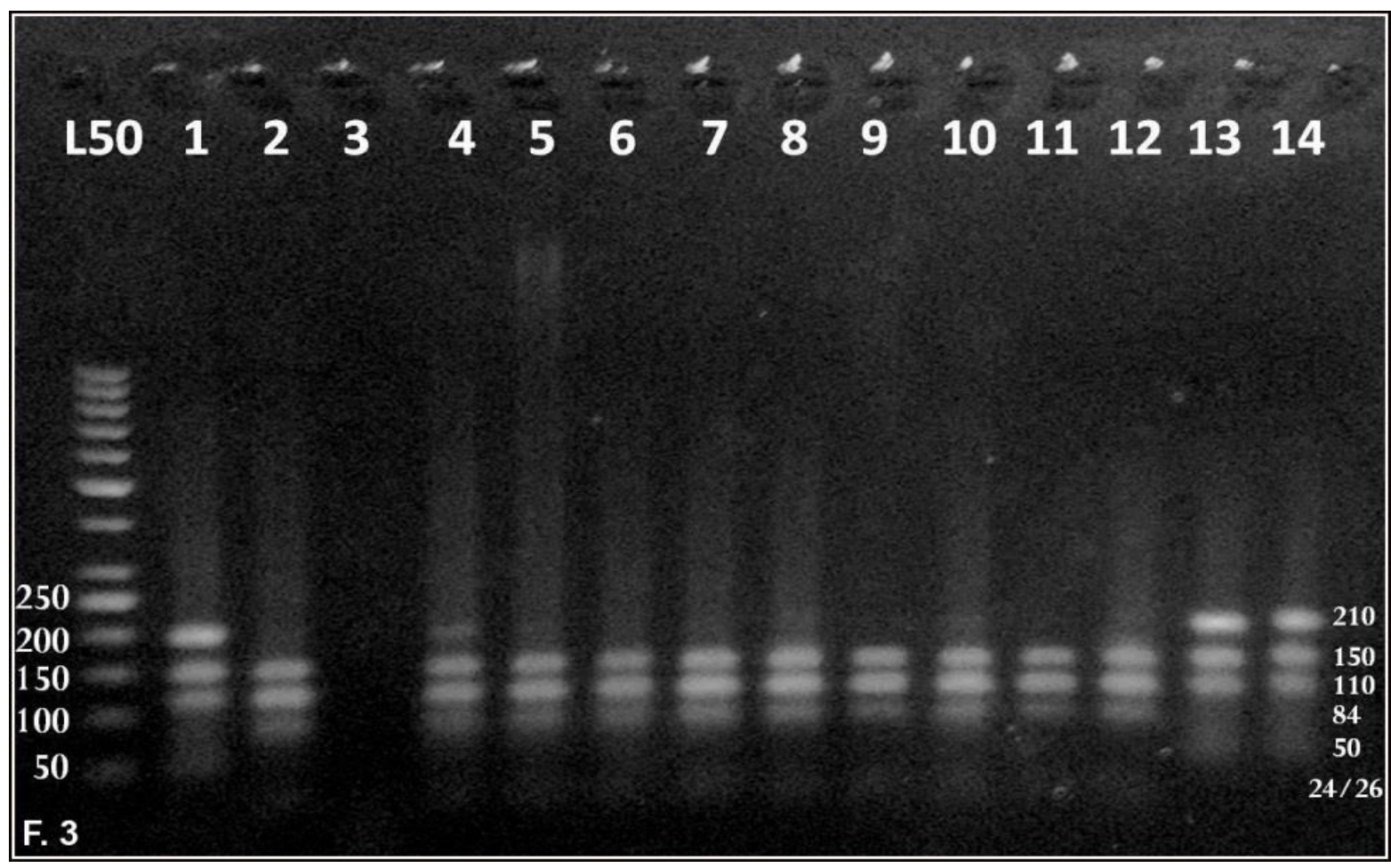

Fig. 3: nPCR-RFLP product following digestion of Giardia samples targeting $B$-giardin gene with endonuclease visualized on agarose gel: Lane (L50) MW marker of $50 \mathrm{bp}$, L1: Positive control assemblage A showing bands at 50 (faint), 110, 150 \& $210 \mathrm{bp}$, L2: Positive control assemblage B showing bands at 24/26 (faint), 84, 117, \& 150 bp, L3: Negative control samples, L5-12: assemblage B digestion product, L4, 13 \& 14: assemblage A digestion product.

Giardia assemblages' distribution among cases relative to clinical \& demographic data (Tab. 2):

Table 2: Distribution of Giardia assemblages among cases in relation to their clinical and demographic data

\begin{tabular}{|c|c|c|c|c|c|c|}
\hline \multicolumn{3}{|c|}{ Studied population } & Assemblage A $(n=9)$ & Assemblage B $(n=43)$ & Total & $P$-value \\
\hline \multirow{2}{*}{ Groups } & \multirow{2}{*}{\multicolumn{2}{|c|}{$\begin{array}{l}\text { Symptomatic } \\
\text { Asymptomatic }\end{array}$}} & 7 & 36 & 43 & \multirow{2}{*}{0.668} \\
\hline & & & 2 & 7 & 9 & \\
\hline \multirow{5}{*}{$\begin{array}{c}\text { Demographic } \\
\text { data }\end{array}$} & \multirow{3}{*}{ Age } & $<18$ & 9 & 41 & 50 & \multirow{3}{*}{0.316} \\
\hline & & $19-49$ & 0 & 2 & 2 & \\
\hline & & $>50$ & 0 & 0 & 0 & \\
\hline & \multirow{2}{*}{ Gender } & Males & 5 & 23 & 28 & \multirow{2}{*}{0.910} \\
\hline & & Females & 4 & 20 & 24 & \\
\hline \multirow{8}{*}{$\begin{array}{c}\text { Clinical } \\
\text { data }\end{array}$} & \multirow{2}{*}{ Diarrhea } & Present & 4 & 30 & 34 & \multirow{2}{*}{0.146} \\
\hline & & Absent & 5 & 13 & 18 & \\
\hline & \multirow{2}{*}{ Abdominal pain } & Present & 4 & 16 & 20 & \multirow{2}{*}{0.685} \\
\hline & & Absent & 5 & 27 & 32 & \\
\hline & \multirow{2}{*}{ Flatulence } & Present & 0 & 14 & 14 & \multirow{2}{*}{$0.045^{*}$} \\
\hline & & Absent & 9 & 29 & 38 & \\
\hline & \multirow{2}{*}{ Fever } & Present & 0 & 3 & 3 & \multirow{2}{*}{0.414} \\
\hline & & Absent & 9 & 40 & 49 & \\
\hline
\end{tabular}

Data presented as $\mathrm{n} \&(*) P$ value $<0.05$ was significant

Giardia assemblages had no significant relation regarding whether the studied individuals had symptoms or not $(P=0.668)$ with the predominance of Assemblage B in both groups.

Assemblage B was significantly predominant among all age groups than Assemblage A with no significant difference between age groups $(P$-value $=0.316)$. Also, Assemblage
B was significantly predominant in both males and females without significant difference in the cases' sexes $(P=0.910)$. As to elation between both assemblages and the presented symptoms within the symptomatic group, flatulence was the only the symptom that had significant correlation with Giardia Assemblage B $(P=0.045)$ which was predominant in cases complaining of flatulence. 


\section{Discussion}

Giardia intestinalis is a cosmopolitan unicellular flagellate parasite infecting a variety of animals including man. The genotypes of Giardia intestinalis include 8 Assemblages from A to H (Lasek-Nesselquist et al, 2010). Assemblages A \& B are known to cause $G$ ardiasis in humans and also were detected in various animals (Caccio et al, 2008).

The current study aimed to define the predominant genotypes of $G$. intestinalis among cases attending Kasr Al-Ainy Hospitals, Cairo and to correlate $G$. intestinalis assemblages with the clinical and demographic data of the cases. Giardiasis causes diversity of clinical forms extending from asymptomatic carriers, to acute or chronic disease (Eckman, 2003).

In the present study, diarrhea, abdominal pain and flatulence were the predominant symptoms. This matches previously reported findings who reported the occurrence of abdominal pain in $50-80 \%$ of patients infected with Giardia (Heresi et al, 2000; D'Anchino et al, 2002; Hill and Nash, 2006).

In the studied groups, asymptomatic carriers were $6.25 \%$ of the asymptomatic individuals. In immuno-competent persons giardiasis was self-limiting and might pass without clinical symptoms (Eckman, 2003).

There epidemiological evidence suggested that infection with $G$. intestinalis has the capability to modulate the host immune system, which may be influenced by concomitant infections with enteric pathogens. In previous studies, $G$. intestinalis infection was associated with infections as Cryptosporidium spp. (Wang et al, 2013), Blastocystis spp. (Elghareeb et al, 2015) and enteric bacteria (Ankarklev et al, 2012; Júlio et al, 2012; Eldash et al, 2013; Krumkamp et al, 2015).

In the present study, the mixed parasitic infection in concomitant with Giardia infection in seven samples within the symptomatic group only, including Entamoeba histolytica/dispar complex, Blastocystis spp. and Entamoeba coli. More research should be directed to clarify the physiological and immunological mechanisms and the influence of concomitant infection on the virulence and final outcome of Giardia infection.

Various molecular techniques including the Nested-PCR followed by PCR-RFLP were used to study the epidemiology and animal role in human infection and to discriminate Giardia assemblages (Feng and Xiao, 2011). PCR-RFLP is a simple, reliable and rapid technique used for genotyping characterization and it yields the same results of the sequencing (Lubeck and Hoorfar, 2003).

In this study, $\beta$-giardin genes were used, through sequence analysis of this locus, isolates can be grouped into assemblages from A to $G$. The benefit of targeting $\beta$-giardin in the molecular detection of Giardia spp. is their unique existence in this parasite (Faubert, 2000; Caccio et al, 2002; Read et al, 2004). However, some authors preferred tpi gene because of its high genetic heterogeneity (Thompson and Monis, 2004).

In the present study, out of 62 Giardia positive stool samples by microscopy, 52 cases $(84 \%)$ were positive by PCR targeting $\beta$-giardin locus. The negative results $(16 \%$ of the samples) could be related to the existence of inhibitors in the samples (Abbaszadegan et al, 2007), sample storage conditions, DNA extraction method or the gene targeted, the choice of primers and the cycling settings that might affect the success of DNA amplification (Gasser, 2006). The most important reason for false negatives was the variances between Giardia strains including; insertion-deletion events, singlenucleotide polymorphisms and rearrangements of the chromosomes. These variances, combined with overall nucleotide identities ranging from $70-80 \%$, have led some to observe that these assemblages could be considered to be different species (Franzen et al, 2009; Jerlstrom-Hultqvist et al, 2010).

In the current study, the isolated genotypes of Giardia from symptomatic and apparently healthy asymptomatic Egyptian Cases showed a significant predominance of assemblage 
$\mathrm{B}$ in all studied groups representing $83.7 \%$ of the symptomatic group and $77.8 \%$ of the cases in asymptomatic group without reported mixed Assemblages in our samples. In agreement with the present study, Assemblage B was $80 \%$ prevalent among Egyptians living in two west Nile Delta Governorates (Foronda et al, 2008). Furthermore, PCR-RFLP targeting tpi, bg and gdh loci of 15 positive samples for Giardia reported assemblage B in 13 samples and assemblage $\mathrm{A}$ and $\mathrm{E}$ in one sample each (Soliman et al, 2011) Moreover, in Kafr-Elshiekh Governorate assemblage $\mathrm{B}$ was higher than the assemblage A (Amer, 2013). In Dakahlia Governorate, it was reported higher incidence of assemblage B (62.14\%) than assemblage A $(31.07 \%)$ in diarrheic children and they also found mixed assemblages (A $\&$ B) in $2.91 \%$ of the cases (El-Tantawy and Taman, 2014). Controversially, a case-control study using PCR-RFLP targeting tpi gene among symptomatic and asymptomatic cases and reported that $47.19 \%, 17.98 \%$ and $11.23 \%$ of the cases were assemblage AI, AII and B respectively, $21.35 \%$ of the cases had mixed genotypes and false negative results up to $2.25 \%$, they also stated that no significant difference in the assemblage distribution among studied individuals (AbdelMoniem and Sultan, 2008). Also, another hospital-based study was done in Egypt targeting tpi gene stated that assemblage A $(75.6 \%)$ was higher than assemblage B 19.4\% (Helmy et al, 2009). Besides, a study targeting $g d h$ by PCR-RFLP in Menofia and Sharkia Governorates revealed that assemblage AII $(83.33 \%, 70.59 \%)$ was higher than assemblage BIII $(16.67 \%, 29.41 \%)$ in cases from Menofia and Sharkia Governorates respectively (Sadek et al, 2013).

The distribution of Giardia assemblages among human cases were varied in the different parts of the world. The frequencies of assemblage B were higher in UK (Amar et al, 2002), Australia (Read et al, 2002), India (Tarub et al, 2004), Thailand (Tungtrongchitr et al, 2010), Saudi Arabia (Al-Moham med, 2011) and Spain (de Lucio et al, 2015), while in Mexico, Brazil, Colombia (EligioGarcia et al, 2008; Lebbad et al, 2008) and Turkey (Sonmez et al, 2015), assemblage A was predominant. This genetic variability in distribution of assemblages' distribution among these countries can be due zoonotic reservoir's role in transmission of the disease beside the geographical distribution.

There was no significant association between Giardia assemblages and the demographic data of the studied groups. This agreed with Ignatius et al. (2012) who reported that age did not matter with assemblage A or B. Also, Anthony et al. (2007); Gelanew et al. (2007) and Anuar et al. (2014) reported a non-significant difference in genders among population infected with either assemblage. Controversy, Mahdy et al. (2009) reported that females had twice higher risk of having assemblage B of Giardia compared to males.

The relation between the clinical presentation and Giardia assemblages had debatable results. In our study, there was a statistically significant association between the assemblage B and flatulence in the studied population. These results agreed with Lebbad et al. (2011) who found that flatulence was significantly more common in cases with $G$. intestinalis assemblage $\mathrm{B}$.

Also, in the present study, diarrhea and abdominal pain was associated with assemblage $\mathrm{B}$ more than assemblage $\mathrm{A}$. It went with similar reports from Egypt (AbdelMoniem and Sultan, 2008), Malaysia (Mahdy et al, 2009), Australia (Yang et al, 2010), Argentina (Molina et al, 2011), Yemen (Alyousefi et al, 2013), Cuba (Puebla et al, 2014) and Turkey (Sonmez et al, 2015).

Controversy, some other reports done in Bangladesh, Spain, Australia and Egypt had stated a statistically significant existence of the symptom within the individuals infected with assemblage A (Read et al, 2002; Haque et al, 2005: Sahagun et al, 2008; Sadek et al, 2013; Fouad et al, 2014). 


\section{Conclusion}

Assemblage B is the predominant genotype found in Egypt in symptomatic and asymptomatic patients. The prevalence of assemblage $\mathrm{B}$ indicates an anthropologic transmission cycle. However, the role of domestic animals and livestock as potential sources of infection for humans in the community also needs to be investigated. There is still a missing point of a clear relation between assemblages and the clinical presentation with contradictory results. This necessitates further work to be clarified through more studies that can guide better understanding of the link between genotypes and different clinical presentations of the infected individuals.

Ethical approval: All procedures performed in studies involving human participants were in accordance with the ethical standards of the institutional and/or national research committee.

Contribution of each author: All the authors contributed to every activity in this manuscript.

Conflict of Interest: The authors declared that they have neither competing interests nor received fund.

\section{References}

Abbaszadegan, MR, Velayati, A, Tavasoli, A, Ryu, H, 2007: Rapid DNA extraction protocol from stool suitable for molecular genetic diagnosis of colon cancer. IBJ 11:203-8.

Abdel-Moneim, SM, Sultan, DM, 2008: Genetic characterization of Giardia isolates from Egyptian patients with relation to clinical giardiasis. J. Egypt. Soc. Parasitol 38, 2:547-60.

Al-Mohammed, HI, 2011: Genotypes of Giardia intestinalis clinical isolates of gastrointestinal symptomatic and asymptomatic Saudi children. Parasitol. Res. 108:1375-81.

Alyousefi, NA, Mahdy, MA, Xiao, L, Mahmud, R, Lim, YA, 2013: Molecular characterization of Giardia duodenalis in Yemen. Exp. Parasitol. 134:141-7.

Amar, C, Dear, P, Pedraza-Diaze, S, Looker, N, Linnane, E, et al, 2002: Sensitivity PCR-restriction fragment length polymorphism assay for detection and genotyping of Giardia duodenalis in human feces. J. Clin. Microbiol. 40:44652.
Amer, SE, 2013: Genotypic and phylogenetic characterization of Giardia intestinalis from human and dairy cattle in Kafr El Sheikh Governorate, Egypt. J. Egypt. Soc. Parasitol. 43, 1: $133-46$.

Ankarklev, J, Hestvik, E, Lebbad, M, Lindh, J, Kaddu-Mulindwa, DH, et al, 2012: Common coinfections of Giardia intestinalis and Helicobacter pylori in non-symptomatic Ugandan Children. PLoS Negl. Trop. Dis 6:e1780.

Anthony, J-P, Fyfe, L, Stewart, D, McDouga11, GJ, Smith, HV, 2007: The effect of blueberry extracts on Giardia duodenalis viability and spontaneous excystation of Cryptosporidium parvum oocysts, in vitro. Methods 42:339-48.

Anuar, ST, Azreen, NS, Saleh, MF, Moktar, N, 2014: Molecular epidemiology of giardiasis among Orang Asli in Malaysia: application of the triosephosphate isomerase gene. BMC Infect. Dis 14, 1:78.

Cacció, SM, Beck, R, Lalle, M, Marinculic, A, Pozio, E, 2008: Multilocus genotyping of Giardia duodenalis reveals striking differences between assemblages A and B Int. J. Parasitol. 38: 1523-31.

Cacciò. SM, Giacomo, M, Pozio, E, 2002: Sequence analysis of the $\beta$-giardin gene and development of a polymerase chain reaction-restriction fragment length polymorphism assay to genotype Giardia duodenalis cysts from human faecal samples. Int. J. Parasitol. 32:1023-30.

Caccio, SM, Ryan, U, 2008: Molecular epidemiology of giardiasis. Mol. Biochem. Parasitol. 160:75-80.

Chevallet, M, Luche, S, Rabilloud, T, 2006: Silver staining of proteins in polyacrylamide gels. Nat. Protoc. 1, 4:1852-8.

D'Anchino, M, Orlando, D, Defeudis, L, 2002: Giardia lamblia infections become clinically evident by eliciting symptoms of irritable bowel syndrome. J. Infect. 45:169-72.

De Lucio, A, Martínez-Ruiz, R, Merino, FJ, Bailo, B, Aguilera, M. et al, 2015: Molecular genotyping of Giardia duodenalis isolates from symptomatic individuals attending two Major Public Hospitals in Madrid, Spain. PLoS ONE 10, 12:e0143981.

Eckmann, L, 2003: Mucosal defences against Giardia. Parasit. Immunol. 25:259-70.

Eldash, HH, Bekhit, OE, Algameel, AA, 2013: Impact of Helicobacter pylori-giardiasis coinfection on children with recurrent abdominal pain. J. Egypt. Soc. Parasitol. 43, 2:509-16. 
Elghareeb, AS, Younis, MS, El Fakahany, A F, Nagaty, IM, Nagib, MM, 2015: Laboratory diagnosis of Blastocystis spp. in diarrheic patients. Trop. Parasitol. 5:36-41.

Eligio-Garcia, L, Cortes-Campos, A, CotaGuajardo, S, Gaxiola, S, Jiménez-Cardoso, E, 2008: Frequency of Giardia intestinalis assemblages isolated from dogs and humans in a comunity from Culiacan, Sinaloa, Mexico using bgiardin restriction gene. Vet. Parasitol. 156:2059.

El-Tantawy, N, Taman, A, 2014: The epidemiology of Giardia intestinalis assemblages A and B among Egyptian children with diarrhea: A PCR-RFLP-based approach. J. Egypt. Parasitol. United 7, 2:104-9.

Faubert, G, 2000: Immune response to Giardia duodenalis. Clin. Microbiol. Rev.13:35-54.

Fayer, R, Morgan, U, Upton, SJ, 2000: Epidemiology of Cryptosporidium: transmission, detection and identification. Int. J. Parasitol. 30: 1305-22.

Feng Y, Xiao L, 2011: Zoonotic potential and molecular epidemiology of Giardia species and giardiasis. Clin. Microbiol. Rev. 24, 1:110-40.

Fontaine, M, Guillot E, 2006: Development of a TaqMan quantitative PCR assay specific for Cryptosporidium parvum. FEMS Microbiol. Letters 214, 1:13-7.

Foronda, P, Bargues, M, Abreu-Acosta, N, Periago, M, Valero, M, et al, 2008: Identification of genotypes of Giardia intestinalis of hum an isolates in Egypt. Parasitol. Res. 103:117781.

Fouad, SA, Esmat, S, Basyoni, MM, Farhan, MS, Kobaisi, MH, 2014: Molecular identification of Giardia intestinalis in patients with dyspepsia. Digest 90:63-71.

Franzen, O, Jerlstrom-Hultqvist, J, Castro, E, Sherwood, E, Ankarklev, J, et al, 2009: Draft genome sequencing of Giardia intestinalis assemblage B isolate GS: are human giardiasis caused by two different species? PLoS Pathog 5, 8:e1000560.

Garcia, LS, 2007: Diagnostic Medical Parasitology, ASM Press, Washington DC.

Gasser, RB, 2006: Molecular tools- advances, opportunities and prospects. Vet. Parasitol. 136: 69-89.

Gelanew, T, Lalle, M, Hailu, A, Pozio, E, Cacciò, S, 2007: Molecular characterization of human isolates of Giardia duodenalis from Ethiopia. Acta Trop. 102, 2:92-9.
Ghosh, S, Debnath, A, Sil, A, De S, Chattopadhyay, DJ, et al, 2000: PCR detection of Giardia lamblia in stool: targeting intergenic spacer region of multicopy rRNA gene. Mol. Cell. Probes14:181-9.

Haque R, Roy S, Kabir M, Stroup SE, Mondal D et al, 2005: Giardia assemblage A infection and diarrhea in Bangladesh. J. Infect. Dis. 192:2171-3.

Helmy, MM, Abdel-Fattah, HS, Rashed, L, 2009: Realtime PCR-RFLP assay to detect $\mathrm{Gi}^{-}$ ardia intestinalis genotypes in human isolates with diarrhea in Egypt. J. Parasitol. 95, 4:1-5.

Heresi, GP, Murphy, JR, Cleary, TG, 2000: Giardiasis. Semi. Ped. Infect. Dis. J. 11:189-95.

Hill, DR, Nash, TE, 2006: Intestinal flagellate and ciliate infections. In: Principles, Pathogens \& Practice. Guerrant RL, Walker DH, Weller PF, eds. Trop. Infect. Dis. Elsevier, Philadelphia. Ignatius, R, Gahutu, JB, Klotz, C, Steininger, C, Shyiramber, C, et al, 2012: High prevalence of Giardia duodenalis Assemblage B infection and association with underweight in Rwandan children. PLoS Neg. Trop. Dis 6:e1677

Jerlstrom-Hultqvist, J, Franzen, O, Ankarkl ev, J, Xu, F, Nohynkova, E, et al, 2010: Genome analysis and comparative genomics of a $\mathrm{Gi}$ ardia intestinalis assemblage $\mathrm{E}$ isolate. BMC Genomics 11:543-9.

Júlio, C, Vilares, A, Oleastro, M, Ferreira, I, Gomes, S, et al, 2012: Prevalence and risk factors for Giardia duodenalis infection among children: a case study in Portugal. Parasit. Vectors 5:22-8.

Krumkamp, R, Sarpong, N, Schwarz, NG, Adlkofer, J, Loag, W. et al, 2015: Gastrointestinal infections \& diarrheal disease in Ghanaian infants and children: an outpatient case-control study. PLoS Negl. Trop. Dis 9: e0003568.

Lalle, M, Pozi, E, Capelli, G, Bruschi, F, Crotti, D, et al, 2005: Genetic heterogeneity at the $\beta$-giardin locus among human and animal isolates of Giardia duodenalis and identification of potentially zoonotic subgenotypes. Int. J. Parasitol. 35, 2:207-13.

Lasek-Nesselquist, E, Welch, DM, Sogin, ML, 2010: The identification of a new Giardia duodenalis assemblage in marine vertebrates and a preliminary analysis of $G$. duodenalis population biology in marine systems. Int. J. Parasitol. 40, 9:1063-74.

Lebbad, M, Ankarklev, J, Tellez, A, Leiva, B, Andersson, JO, et al, 2008: Dominance of $\mathrm{Gi}^{-}$ 
ardia Assemblage B in Leon, Nicaragua. Acta Trop. 106:44-53.

Lebbad, M, Petersson, I, Karlsson, L, BoteroKleiven, S, Andersson, JO, et al, 2011: Multil ocus genotyping of human Giardia isolates suggests limited zoonotic transmission and association between Assemblage B and flatulence in children. PLoS Negl. Trop. Dis. 5, 8:e1262.

Lubeck PS, Hoorfar J, 2003: PCR Technology and applications to zoonotic food-borne bacterial pathogens. Methods Mol. Biol. 216, 4:65-84.

Mahdy, MAK, Surin, J, Mohd-Adnan, A, Wan, KL, Lim, YAL, 2009: Molecular characterization of Giardia duodenalis isolated from Semai Pahang Orang Asli. Parasitol. 14:123741.

Molina, N, Pezzani, B, Ciarmela, M, Orden, A, Rosa, D, et al, 2011: Intestinal parasites and genotypes of Giardia intestinalis in school children from Berisso, Argentina. J. Infect. Dev. Ctries 5, 7:527-34.

Monis, PT, Caccio, SM, Thompson, R, 2009: Variation in Giardia: towards a taxonomic revision of the genus. Trends Parasitol. 25:93-100.

Puebla, LJ, Núñez, FA, Fernández, YA, Fraga, J, Rivero, LR, et al, 2014: Correlation of Giardia duodenalis assemblages with clinical and epidemiological data in Cuban children. Infect. Genet. Evol. 23:7-12.

Read, C, Walters, J, Robertson, R, 2002: Correlation between genotypes of Giardia duodenalis and diarrhea. Int. J. Parasitol. 32:229-31.

Read, CM, Monis, PT, Thompson, RC, 2004: Discrimination of all genotypes of Giardia duodenalis at the glutamate dehydrogenase locus using PCR-RFLP. Infect. Genet. Evol. 4:125-30.

Sadek, GS, El-Settawy, MA, Soha, A, Nasr, S A, 2013: Genotypic characterization of Giardia duodenalis in children in Menoufia and Sharkia Governorates. Egypt. Life Sci. J. 10, 1:4006-15.

Sahagún, J, Clavel, A, Goñi, P, Seral, C, Llorente, MT, et al, 2008: Correlation between the presence of symptoms and the Giardia duodenalis genotype. Eur. J. Clin. Microbiol. Infect. Dis. 27:81-3.

Savioli, L, Smith, H, Thompson, A, 2006: $G i-$ ardia and Cryptosporidium join the neglected diseases initiative. Trends Parasitol. 22, 5:203-8.
Soliman, RH, Fuentes, I, Rubio, JM, 2011: Identification of a novel assemblage B subgenotype and a zoonotic assemblage in human isolates of Giardia intestinalis in Egypt. Parasitol. Int. 60:507-11.

Sonmez, TG, Kasap, M, Kadir, D, 2015: Genotyping and phylogenetic analysis of Giardia duodenalis isolates from Turkish Children. Med. Sci. Monit. 21:526-32.

Tarub, R, Monis, P, Robertson, I, Irwin, P, Mencke, N, Thompson, R, 2004: Epidemiological and molecular evidences support the zoonotic transmission of Giardia among humans and dogs living in the same community. Parasitology 128:253-62.

Thompson, RC, Smith, A, 2011: Zoonotic enteric protozoa. Vet. Parasitol. 182, 1:70-8.

Thompson, RCA, Monis, PT, 2004: Variation in Giardia: Implications for taxonomy and epidemiology. Adv. Parasitol. 58:69-137.

Tsourdi, E, Heidrich, FM, Winzer, M, Röllig, C, Kirsch, C, et al, 2014: An exotic cause of exudative enteropathy. Am. J. Case Rep. 15:226-9.

Tungtrongchitr, A, Sookrung, N, Indrawattana, N, Kwangsi, S, Ongrotchanaku, J, et al, 2010: Giardia intestinalis in Thailand: identification of genotypes. J. Hlth. Popul. Nutr. 28, 1: 42-52.

Verweij, JJ, Blangé, RA, Templeton, K, Schinkel, J, Brienen, EA, et al, 2004: Simultaneous detection of Entamoeba histolytica, Giardia lamblia, and Cryptosporidium parvum in fecal samples by using multiplex real-time PCR. J. Clin. Microbiol. 42, 3:1220-3.

Wang, L, Xiao, L, Duan, L, Ye, J, Guo, Y, et al, 2013: Concurrent infections of Giardia duodenalis, Enterocytozoon bieneusi, and Clostridium difficile in children during a cryptosporidiosis outbreak in a pediatric hospital in China. PLoS Negl. Trop. Dis. 7:e2437.

Yang, R, Lee, J, Ng, J, Ryan, U, 2010: High prevalence Giardia duodenalis assemblage B and potentially zoonotic subtypes in sporadic human cases in Western Australia. Int. J. Parasitol. 40:293-7. 